\title{
PENGARUH IMPLEMENTASI SAFETY MANAGEMENT SYSTEM TERHADAP PELAYANAN NAVIGASI PENERBANGAN
}

\author{
Putu Krisna Surya Wardana ${ }^{(1)}$, Dwi Lestary ${ }^{(2)}$, Pangsa Rizkina Aswia ${ }^{(3)}$ \\ ${ }^{1,2,3}$ Politeknik Penerbangan Indonesia Curug \\ e-mail: ${ }^{1}$ putu.krisnasw@gmail.com, ${ }^{2}$ dwi.lestary@ ppicurug.ac.id \\ ${ }^{3}$ pangsa.rizkina@ppicurug.ac.id
}

Abstrak: Penelitian ini bertujuan untuk mengetahui pengaruh Implementasi Safety Management System (SMS) terhadap Pelayanan Navigasi Penerbangan di Perum Lembaga Penyelenggara Pelayanan Navigasi Penerbangan Indonesia (LPPNPI) Cabang Banjarmasin. Penelitian ini menggunakan analisis kuantitatif di mana metode pengumpulan datanya menggunakan angket/kuesioner, analisis SMS Gap Analysis Checklist dan studi dokumentasi sedangkan pengolahan data dilakukan dengan SPSS dengan sampel 22 responden serta taraf kesalahan 5\% yang ditujukan kepada personel ATC di Perum LPPNPI Cabang Banjarmasin. SMS Gap Analysis Checklist diisi oleh Manajer Keselamatan, Keamanan dan Standarisasi. Kesimpulan penelitian ini adalah diketahui bahwa terdapat hubungan yang signifikan dan pengaruh antara Implementasi SMS terhadap Pelayanan Navigasi Penerbangan dengan nilai koefisien sebesar 0,786 dan koefisien determinasi sebesar 62\%. SMS Gap Analysis Checklist, hasilnya menunjukkan bahwa Implementasi SMS di Perum LPPNPI Cabang Banjarmasin berada di tahap I yaitu perencanaan implementasi SMS. Hasil penelitian diharapkan dapat menjadi sumber dalam mengevaluasi Implementasi SMS serta meningkatkan Pelayanan Navigasi Penerbangan di Perum LPPNPI Cabang Banjarmasin.

Kata Kunci: implementasi safety management system (SMS), navigasi penerbangan, pelayanan, perencanaan.

Abstract: $\quad$ This study aims to determine the effect of the Implementation of the Safety Management System (SMS) to Air Navigation Services at Perum LPPNPI of Banjarmasin Branch. This study used quantitative analysis in which the data collection method used a questionnaire, analysis of the SMS Gap Analysis Checklist and documentation studies while data processing was carried out by SPSS with a sample of 22 respondents and an error rate of $5 \%$ which is addressed to ATC personnel at Perum LPPNPI of Banjarmasin Branch. The SMS Gap Analysis Checklist was filled out by the Manager of Safety, Security and Standardization. The conclusion of

http://journal.ppicurug.ac.id/index.php/jurnal-langit-biru 
this study is it is known that there was a significant relationship and influence between the implementation of SMS on Air Navigation Services with a coefficient value of 0.786 and a coefficient of determination of $62 \%$. SMS Gap Analysis Checklist, the results showed that the SMS Implementation at Perum LPPNPI of Banjarmasin Branch was in stage I, namely SMS implementation planning. The results of the research were expected to be a source in evaluating the implementation of SMS and improving Air Navigation Service at Perum LPPNPI of Banjarmasin Branch.

Keyword: $\quad$ the implementation of SMS, air navigation, services, planning

\section{Pendahuluan}

Bandar Udara Syamsudin Noor merupakan salah satu Bandar Udara yang melayani penerbangan di Kalimantan Selatan khususnya di Kecamatan Landasan Ulin, Kota Banjarbaru, dan juga menjadi penghubung antara Indonesia bagian timur dan barat karena terletak di Indonesia bagian tengah. Bandara ini terus mengalami peningkatan jumlah traffic diikuti kenaikan jumlah penumpang tiap tahunnya,

Dengan terjadinya peningkatan tersebut maka dibutuhkan penanganan yang baik, khususnya kualitas pelayanan jasa pemanduan lalu lintas udara yang perlu ditingkatkan. Pencegahan incident dan accident harus dilaksanakan, maka dikembangkanlah suatu sistem tersendiri yang mengatur tentang bagaimana menekan angka kecelakaan dengan membuat suatu metode pelaporan dan pencatatan kecelakaan yang mendeteksi bahaya (hazard), menganalisis konsekuensi serta risiko (risk) dan mensosialisasikan analisis tersebut kepada pihak-pihak yang terkait.

Sistem tersebut dikenal dengan Sistem Manajemen Keselamatan (Safety
Management System/SMS). Safety Management System (SMS) berarti suatu pendekatan sistematis untuk mengelola keselamatan, termasuk struktur organisasi yang diperlukan, kewajiban, kebijakan dan prosedur, (KM 20 tahun 2009). Safety Management System (SMS) ini juga diamanatkan dalam UU Republik Indonesia Nomor 1 tahun 2009 tentang Penerbangan bagian ke empat pasal 314 ayat (1) yang berbunyi: "Setiap penyedia jasa penerbangan wajib membuat, melaksanakan, mengevaluasi, dan menyempurnakan secara berkelanjutan sistem manajemen keselamatan (safety management system) dengan berpedoman pada program keselamatan penerbangan nasional". Selain itu juga, sebagaimana rekomendasi ICAO pada Annexes 19 Safety Management System dan ICAO Doc 9859 Safety Management Manual.

Perum LPPNPI Cabang Banjarmasin telah menerapkan Safety Management System namun peranan SMS belum optimal. Penulis menemukan fenomena terkait masalah safety yaitu belum terdapatnya VFR Corridor untuk penerbangan pesawat latih menyebabkan tidak adanya acuan 
Pengaruh Implementasi Safety Management SystemTerhadap Pelayanan Navigasi Penerbangan

pasti posisi pesawat sehingga tidak menutup kemungkinan terjadinya near miss dengan kondisi traffic semakin lama semakin meningkat. Hal ini juga diungkapkan pada penelitian sebelumnya, pada tahun 2017 tentang Penerapan Safety Management System dan Kompetensi Pemandu Lalu Lintas Penerbangan.

Adapun tujuan penelitian ini, sebagai berikut:

a. Mengetahui implementasi safety management system (SMS) di Perum LPPNPI Cabang Banjarmasin.

b. Mengetahui pelayanan navigasi penerbangan di Perum LPPNPI Cabang Banjarmasin.

Mengetahui pengaruh implementasi safety management system (SMS) terhadap pelayanan navigasi penerbangan di Perum LPPNPI Cabang Banjarmasin.

\section{Metode}

Dalam penelitian ini, peneliti menggunakan metode penelitian analisis kuantitatif yang disebut juga metode tradisional, karena metode ini sudah cukup lama digunakan sehingga sudah mentradisi sebagai metode untuk penelitian. Data penelitian pada metode ini berupa angka-angka dan analisis menggunakan statistik (Sugiyono, 2019).

Peneliti membagi variabelvariabel yang akan diteliti menjadi dua yaitu :

a. Variabel Bebas (independen)

Variabel ini sering disebut sebagai variabel stimulus, predictor, antecedent. Variabel bebas adalah variabel yang mempengaruhi atau yang menjadi sebab perubahannya atau timbulnya variabel dependen (Sugiyono, 2019). Dalam penelitian ini variabel $\mathrm{X}$ atau variabel bebas adalah Implementasi Safety Management System.

b. Variabel Terikat (dependen)

Variabel ini sering disebut sebagai variabel output, kriteria, konsekuen. Variabel terikat merupakan variabel yang dipengaruhi atau yang menjadi akibat karena adanya variabel bebas (Sugiyono, 2019). Dalam penelitian ini variabel $\mathrm{Y}$ atau variabel terikat adalah Pelayanan Navigasi Penerbangan.

Tabel 1. Dimensi dan indikator variable $X$

\begin{tabular}{|c|l|ll|}
\hline No & \multicolumn{1}{|c|}{ DIMENSI } & \multicolumn{1}{|c|}{ INDIKATOR } \\
\hline 1. & Safey Policy and Objectives & - & Komitmen dan tanggung jawab manajemen \\
& & - & Pertanggung jawaban keamanan \\
& & Dokumentasi SMS \\
\hline 2. & Safety Risk Management & - & Mengidentifikasi adanya bahaya (hazard) \\
& & - & Penilaian dan mitigasi risiko keselamatan \\
\hline 3. & Safety Assurance & - & Adanya pemantauan dan pengukuran kinerja keselamatan \\
& & - & Adanya prosedur pengelolaan perubahan \\
& & - & $\begin{array}{l}\text { Perbaikan berkelanjutan yang berkaitan dengan Safety } \\
\text { Management System }\end{array}$ \\
\hline 4. & Safety Promotion & - & $\begin{array}{l}\text { Adanya pelatihan dan pendidikan } \\
\text { Adanya komunikasi keselamatan penerbangan }\end{array}$ \\
\hline
\end{tabular}


Langit Biru: Jurnal Ilmiah Aviasi Vol. 14 No. 1 Februari 2021

ISSN (p) 1979-1534 ISSN (e) 2745-8695

Tabel 2. Dimensi dan indikator variable $Y$

\begin{tabular}{|c|l|ll|}
\hline No & \multicolumn{1}{|c|}{ DIMENSI } & \multicolumn{1}{c|}{ INDIKATOR } \\
\hline 1 & Keselamatan & $-\begin{array}{l}\text { Tidak terjadi BOS (Breakdown of Separation) dan BOC } \\
\text { (Breakdown of Coordination) } \\
\text { Tidak terjadi } \text { incident maupun accident }\end{array}$ \\
\hline 2 & Kelancaran & - & Tidak terjadi delay atau holding di darat maupun udara \\
\hline 3. & Keteraturan & $-\begin{array}{l}\text { Terampil dan tepat dalam menentukan urutan landing } \\
\text { maupun take off (sequencing) }\end{array}$ \\
\hline
\end{tabular}

\section{Metode Pengumpulan Data}

Teknik pengumpulan data yang digunakan dalam mendapatkan dan mengumpulkan penjelasan data yang berhubungan dengan masalah pada penelitian ini adalah sebagai berikut:

a. Angket (Kuesioner)

Angket (Kuesioner) adalah teknik pengumpulan data dengan menyerahkan atau mengirimkan daftar pertanyaan untuk diisi sendiri oleh responden (Aminarno, 2019). Dalam penelitian ini peneliti menggunakan kuesioner tertutup yaitu responden memilih jawaban yang sudah ada. Adapun teknis yang digunakan dalam penyebaran angket atau kuesioner ini yaitu diberikan kepada seluruh pemandu lalu lintas udara yang tersebar di Divisi Pelayanan Aerodrome Control Tower dan Approach Control Unit di Perum LPPNPI Cabang Banjarmasin.

b. Studi Dokumentasi

Studi Dokumentasi adalah teknik pengumpulan data yang tidak langsung ditujukan kepada subyek penelitian (Aminarno, 2019). Dalam hal ini peneliti mengamati, mempelajari, dan memperoleh data yang memuat masalah SMS dari sumber lain seperti dokumen International Civil Aviation Organization (ICAO), Annexes, buku ilmu pengetahuan, literatur, laporan kerja, dan lain-lain.

\section{Metode Analisis Data}

Di dalam mengolah data, peneliti melakukan analisis terhadap data yang diperoleh dengan menggunakan analisis kuantitatif. Teknik analisis data dalam penelitian kuantitatif ini menggunakan teknik korelasional dimana analisis data bertujuan untuk menguji hipotesis yang telah diajukan sebelumnya. Analisis data yang dilakukan meliputi uji persyaratan analisis data sebagai persyaratan penggunaan analisis dan teknik pengujian hipotesis. Proses perhitungan dengan menggunakan analisis kuantitatif dilakukan melalui proses berikut : skala likert, uji validitas, uji reliabilitas, uji normalitas, uji lineritas, analisis korelasi, analisis regresi linier sederhana, koefisien determinasi.

\section{Diskusi}

Analisis regresi linier dilakukan dengan Implementasi Safety Management System (X) sebagai variabel bebas serta PeIayanan Navigasi Penerbangan (Y) sebagai variabel terikat. Persamaan regresi adalah sebagai berikut : 
Pengaruh Implementasi Safety Management SystemTerhadap Pelayanan Navigasi Penerbangan

Tabel 3

Total Jawaban SMS Gap Analysis Checklist

\begin{tabular}{|l|c|c|}
\hline $\begin{array}{l}\text { Semua } \\
\text { Komponen }\end{array}$ & Jumlah & Presentase \\
\hline $\begin{array}{l}\text { Telah } \\
\text { Dilaksanakan }\end{array}$ & 62 & $87 \%$ \\
\hline $\begin{array}{l}\text { Dalam Proses } \\
\text { Pelaksanaan }\end{array}$ & 4 & $6 \%$ \\
\hline $\begin{array}{l}\text { Tidak } \\
\text { Dilaksanakan }\end{array}$ & 5 & $7 \%$ \\
\hline TOTAL & 71 & $100 \%$ \\
\hline
\end{tabular}

Dari Tabel 3 diatas, terlihat bahwa dari 71 pertanyaan terdapat 62 pertanyaan atau $87 \%$ dijawab "telah dilaksanakan" dan 4 pertanyaan atau 6 $\%$ "dalam proses pelaksanaan" serta 5 pertanyaan atau $7 \%$ "tidak dilaksanakan". Hal ini menunjukkan hampir seluruh elemen yang dipersyaratkan oleh gap analysis checklist telah dilaksanakan. Hasil di atas merupakan presentase elemen SMS yang sudah terimplementasi di Perum LPPNPI Cabang Banjarmasin yaitu sebesar $87 \%$.

Berdasarkan SMS GAP Analysis Checklist, penerapan SMS di Perum LPPNPI Cabang Banjarmasin baru memasuki tahap I yaitu perencanaan implementasi SMS. Pada tahapan ini terdapat persyaratan yang harus dipenuhi terlebih dahulu sebelum melanjutkan kegiatan pada tahapan II.

Tabel 4 Hasil Uji Regresi X dan Y

\begin{tabular}{|c|c|c|c|c|c|c|}
\hline \multicolumn{7}{|c|}{ Coefficients $^{\mathrm{a}}$} \\
\hline \multirow{2}{*}{\multicolumn{2}{|c|}{ Model }} & \multicolumn{2}{|c|}{$\begin{array}{l}\text { Unstandardized } \\
\text { Coefficients }\end{array}$} & \multirow{2}{*}{\begin{tabular}{|l|}
$\begin{array}{l}\text { Standardized } \\
\text { Coefficients }\end{array}$ \\
Beta
\end{tabular}} & \multirow[t]{2}{*}{$\mathrm{t}$} & \multirow[t]{2}{*}{ Sig. } \\
\hline & & $\mathrm{B}$ & Std. Error & & & \\
\hline \multirow[t]{2}{*}{1} & (Constant) & 8.265 & 6.100 & & 1.355 & .191 \\
\hline & $\begin{array}{lll}\text { Implementasi } & \text { Safety } & \text { Management } \\
\text { System } & & \end{array}$ & .813 & .143 & .786 & 5.678 & .000 \\
\hline
\end{tabular}

Tabel 5 Koefisien Determinasi (R square)

\begin{tabular}{|l|l|l|l|l|}
\hline \multicolumn{5}{|l|}{ Model Summary } \\
\hline Model & R & R Square & Adjusted R Square & Std. Error of the Estimate \\
\hline 1 & $.786^{\mathrm{a}}$ & .617 & .598 & 2.435 \\
\hline \multicolumn{4}{|l}{ Predictors: (Constant), Implementasi Safety Management System } \\
\hline
\end{tabular}

Dari tabel 4 di atas diperoleh persamaan regresi sebagai berikut: $\mathbf{Y}=$ $8.265+0.813 \mathrm{X}$. Persamaan regresi linier sederhana dapat dijelaskan bahwa nilai koefisien regresi variabel Implementasi Safety Management System adalah sebesar 0,813, artinya jika variabel Implementasi Safety
Management System mengalami kenaikan 1 satuan, maka nilai dari PeIayanan Navigasi Penerbangan akan mengalami kenaikan sebesar 0,813 poin. Hal itu juga berlaku sebaliknya.

Dari tabel 5 di atas diperoleh koefisien determinasi atau $\mathrm{R}$ Square adalah 0,617 artinya $62 \%$ variabel 
terikat yaitu Pelayanan Navigasi Penerbangan $\quad(\mathrm{Y}) \quad$ variasinya dipengaruhi oleh variabel bebas Implementasi Safety Management System (X) dan sisanya sebesar 38\% dipengaruhi faktor lainnya

Berdasarkan hasil penelitian diperoleh persamaan regresi linier $\mathbf{Y}=$ $\mathbf{8 . 2 6 5}+\mathbf{0 , 8 1 3} \mathrm{X}$ yang artinya apabila variasi nilai pada Implementasi Safety Management System dinaikkan sebanyak 1 satuan maka variasi nilai Pelayanan Navigasi Penerbangan akan naik sebanyak 0,813 pada tingkat konstanta 8.265. selain itu dari hasil penelitian juga dapat diketahui bahwa Implementasi Safety Management System memiliki kaitan yang kuat dengan Pelayanan Navigasi Penerbangan (pearson correlation $\mathrm{r}=0,786$ ), adanya Implementasi Safety Management System memberikan pengaruh sebesar $62 \%$ terhadap Pelayanan Navigasi Penerbangan (38\% dipengaruhi oleh faktor lain yang tidak diteliti dalam penelitian ini).

Kemudian dilihat dari SMS Gap Analysis Checklist untuk implementasi Safety Management System di Perum LPPNPI Cabang Banjarmasin terlihat dari 71 pertanyaan terdapat 62 pertanyaan atau $87 \%$ dijawab "telah dilaksanakan" dan dan 4 pertanyaan atau $6 \%$ "dalam proses pelaksanaan" serta 5 pertanyaan atau $7 \%$ "tidak dilaksanakan". Hal ini menunjukkan masih terdapat beberapa kekurangan sehingga diperlukannya perbaikan seperti yang dipersyaratkan oleh SMS Gap Analysis Checklist. Maka dari itu dapat diketahui bahwa implementasi Safety Management System di Perum LPPNPI Cabang Banjarmasin berdasarkan tahapan implementasi SMS pada Safety Management Manual Doc. 9859, 2013, phased approach yaitu berada pada tahap I - Perencanaan Implementasi Safety Management System (SMS).

\section{Kesimpulan}

Melihat dari hasil analisis di atas, ada beberapa persyaratan yang belum terpenuhi, yaitu sudah ditunjuknya Akuntabel Eksekutif (accountable executive) namun belum secara penuh bertanggung jawab langsung terhadap pelaksanaan kegiatan perusahaan terkait SMS. belum maksimalnya Safety Committee atau Review Board dan Safety Action Group untuk tujuan meninjau kinerja SMS dan keselamatan, belum adanya prosedur untuk peninjauan berkala terhadap ERP, dan belum adanya prosedur untuk tindakan korektif atau tindak lanjut ketika target tidak tercapai dan level dilampaui/dilanggar. Berkaitan dengan hal tersebut di atas, peneliti berkeinginan untuk menyumbangkan ide dalam bentuk rekomendasi sebagai upaya untuk meningkatkan implementasi SMS dalam pelayanan navigasi penerbangan di Perum LPPNPI Cabang Banjarmasin, sebagai berikut :

1. Mempertegas kembali tugas dan tanggung jawab General Manager dan dituang di dalam manual SMS.

2. Melakukan evaluasi terhadap efektifitas pelaksanaan manajemen risiko keselamatan terhadap pencegahan bahaya.

3. Mengevaluasi dan memaksimalkan tugas Safety Committee atau Review board dan Safety Action Group yang 
Pengaruh Implementasi Safety Management SystemTerhadap Pelayanan Navigasi Penerbangan

ada di Perum LPPNPI Cabang Banjarmasin

4. Peningkatan pelayanan navigasi penerbangan melalui pendidikan dan pelatihan

\section{Daftar Pustaka}

Aminarno Budi Pradana, Drs, S.Si.T, MM. (2019). Metode Penelitian Ilmiah. Tangerang: Sekolah Tinggi Penerbangan Indonesia

Civil Aviation Safety Regulation.Part 172. (2009). Air Traffic Service Provider.

International Civil Aviation Organization. (2001). Document 9774. Manual on Certification of Aerodromes. Montreal: Secretary General.

International Civil Aviation Organization. (2016). Annex 19. Safety Management ( $2^{\text {nd }}$ ed.). Montreal: Secretary General.

International Civil Aviation Organization. (2018). Annex 11. Air Traffic Services (15 ${ }^{\text {th }}$ ed.).

International Civil Aviation Organization. (2018). Document 9859. Safety Management Manual $\quad(\mathrm{SMM}) \quad\left(4^{\text {th }} \quad\right.$ ed $)$. Montreal: Secretary General.

Mellisa, Anaria Carini., dkk. (2017). Penerapan Safety Management System dan Kompetensi Pemandu Lalu Lintas Penerbangan.

Menteri Perhubungan. KM Nomor 20 Tahun 2017 tentang Peraturan Keselamatan Penerbangan Sipil (PKPS) bagian 19 tentang Sistem Manajemen Keselamatan.

Menteri Perhubungan. SKEP/76/VI/2005 tentang Petunjuk Pelaksanaan Keputusan
Menteri Perhubungan Nomor 47

Tahun 2002 tentang Sertifikasi Operasi Bandar Udara.

Peraturan Pemerintah. Nomor: 3 Tahun 2001 tentang Keamanan dan Keselamatan Penerbangan.

Peraturan Pemerintah. Nomor: 77 Tahun 2012 tentang Perusahaan Umum (Perum) Lembaga Penyelenggara Pelayanan Navigasi Penerbangan Indonesia.

Peraturan Menteri Perhubungan. Nomor: PM Nomor 49 Tahun 2011 tentang Peraturan Keselamatan Penerbangan Sipil (PKPS) bagian 172 tentang penyelenggara Pelayanan Lalu Lintas Penerbangan.

Perum Lembaga Penyelenggara Pelayanan Navigasi Penerbangan Indonesia. (2016). Sistem Manajemen Keselamatan. Tangerang.

Perum Lembaga Penyelenggara Pelayanan Navigasi Penerbangan Indonesia. (2017). Pelatihan Personel Navigasi Penerbangan. Tangerang.

Siregar, Syofian. (2013). Statistik Parametrik Untuk Penelitian Ilmiah ( ${ }^{\text {rd }}$ ed.). Jakarta.

Sugiyono, Prof., Dr. (2019). Metode Penelitian Kuantitatif. Bandung: Alfabeta.

Undang - Undang Republik Indonesia. Nomor: 1 Tahun 2009 tentang Penerbangan. 